\title{
МОРФОЛОГІЧНІ ОСОБЛИВОСТІ ПЕРЕБУДОВИ СТРУКТУРИ ОПОРНО-РУХОВОГО АПАРАТУ ЗА УМОВ ПАТОЛОГІї
}

\author{
Паньків М. В., Пальтов Е. В., Кривко Ю. Я., Жуковський В. С. \\ Львівський національний медичний університет імені Данила Галищького, кафедра нормальної \\ анатомії, м. Львів
}

DOI: https://doi.org/10.31435/rsglobal_ws/30042020/7021

\begin{tabular}{l} 
ARTICLE INFO \\
Received: 22 February 2020 \\
Accepted: 17 April 2020 \\
Published: 30 April 2020 \\
\hline
\end{tabular}

KEYWORDS

musculoskeletal system, restructuring,

pathology.

\begin{abstract}
The aim of our work was to study the scientific information and to systematize the data of domestic and foreign literature concerning the study of morphological features of restructuring of the musculoskeletal system in pathological settings.
\end{abstract}

Citation: Pankiv M. V, Paltov E. V, Kryvko Yu. Ya., Zhukovsky V. S. (2020) Morphological Peculiarities of Restructuring the Structure of the Musculoskeletal System in Pathological Settings. World Science. 4(56), Vol.1. doi: 10.31435/rsglobal_ws/30042020/7021

Copyright: (C) 2020 Pankiv M. V, Paltov E. V, Kryvko Yu. Ya., Zhukovsky V. S. This is an openaccess article distributed under the terms of the Creative Commons Attribution License (CC BY). The use, distribution or reproduction in other forums is permitted, provided the original author(s) or licensor are credited and that the original publication in this journal is cited, in accordance with accepted academic practice. No use, distribution or reproduction is permitted which does not comply with these terms.

Результати статі відповідають плану наукових досліджень Львівського національного медичного університету імені Данила Галицького і $є$ частиною науково-дослідної теми кафедри нормальної анатомії «Структурна організація, ангіоархітектоніки та антропометричні особливості органів у внутрішньо та позаутробному періодах розвитку, за умов екзо- та ендопатогених факторів» (номер держреєстрації 0115U000041), яка виконується впродовж 2015 - 2019 pp.

За даними ВООЗ, захворювання опорно-рухового апарату як причина інвалідності та смертності посідають 4-те місце у світі після серцево-судинних, онкологічних хвороб та цукрового діабету [180], а найближчим часом спеціалісти прогнозують епідемію остеопорозу, що свідчить про старіння населення планети [181]. За статистикою, кожний п'ятий мешканець земної кулі страждає від болю у спині, а частка остеохондрозу при цьому становить до 90\%.

В Україні хронічні захворювання опорно-рухової системи також є однією 3 найбільш частих проблем [81], а близько 3,5 млн осіб по-справжньому знайомі з проблемою опорнорухового апарату, його грізними ускладненнями [57], які вимагають безперервної багаторічної терапії $[63,73]$.

Наведені дані, без сумніву, переконують у необхідності вивчення морфологічних особливостей структури опорно-рухового апарату за умов патології.

Оскільки кожна функція базується на адекватній структурі органа, а іï порушення внаслідок впливу патогенних факторів $є$ підгрунтям для розвитку патологічного процесу, що визначає його характер та особливості клінічних проявів, беззаперечно існує необхідність вивчення структурних змін органа на тлі фонової патології [180-182].

В умовах тотальної гіподинамії, неадекватних фізичних навантажень поєднано 3 впливом зовнішнього середовища, що продовжує забруднюватись внаслідок техногенних катастроф та токсично-наркотичних середників, господарської діяльності людини, патології хребта посідають одне з чільних місць серед проблем сучасної медицини [184-191]. Руйнування хребців внаслідок остеопоротичних змін у кістковій тканині, остеохондроз різних відділів 
хребта веде не лише до різного ступеня вираженості розладів у функціонуванні опорнорухового апарату, але і $є$ причиною розвитку патологічних станів низки органів, структурно та функціонально пов'язаних з хребтом, спинним мозком та спинномозковими нервами [194-200]. Патологічні зміни шийного відділу хребта посідають особливе місце, оскільки одним 3 наслідків кривошиї $є$ порушення кровопостачання через хребтові артерії, а відтак - вертебробазилярна недостатність [171,191]. Як свідчить наукова література, а також офіційна медична статистика, патологічні зміни шийного відділу хребта діагностують у осіб різного віку - від кривошиї у новонароджених до остеохондрозу, остеопенічних та остеопоротичних змін в осіб не лише старечого, але й зрілого і навіть юнацького віку.

Літературний аналіз висотних розмірів міжхребцевих дисків засвідчив, що в обстежуваних осіб як чоловічої, так і жіночої статі співвідношення досліджуваних параметрів і форма дисків є подібними - у 98\% обстежуваних жінок і у $85 \%$ чоловіків диски мають найменшу висоту по задньому краю. Максимальною висота міжхребцевих дисків у 85\% обстежених $є$ по центру, а у 15\% - по передньому краю. У 20\% обстежених осіб встановлено різного ступеня вираженості асиметрію висоти міжхребцевих дисків, що можна трактувати як прояв викривлення шийного відділу хребта ще до розвитку клінічних проявів даної патології.

Проведений аналіз висотних розмірів структурних компонентів шийного відділу хребта осіб юнацького віку засвідчив значну варіабельність форми та розмірів шийних хребців та міжхребцевих дисків у осіб і чоловічої і жіночої статі. Проте встановлені закономірності співвідношення окремих морфометричних параметрів кожної з досліджуваних структур, на нашу думку, відповідають рівню сформованості шийного лордозу, можуть свідчити про розвиток патологічних вигинів і $є$ характерними для осіб кожної статі.

У фаховій літературі трапляються дані щодо променевого обстеження пацієнтів 3 використанням сучасних цифрових методів, зокрема комп'ютерної томографії, дає змогу детально проаналізувати структурні особливості обстежуваної ділянки чи органа, а також визначити їхні фізичні якості, зокрема, щільність досліджуваних тканин, оскільки зміна цього показника може бути свідченням розвитку патологічного стану ще за відсутності його клінічних проявів [186]. Під впливом численних ендо- та екзогенних чинників структура, мінеральний склад, а, відповідно, і щільність кісткової тканини, характеризуються постійною динамікою різного ступеня вираженості та інтенсивності навіть після завершення процесів, які пов'язані з ростом і формуванням скелета [195]. Тому можливість проведення ранньої діагностики патологічних станів, виявляючи зміни щільності досліджуваних структур, передбачає порівняння показників, які отримали обстежуючи пацієнта, 3 нормативними показниками, характерними для осіб певного віку та статі [189].

Проведений авторами аналіз показників щільності кісткової тканини хребців шийного відділу хребта осіб юнацького віку засвідчив значну варіабельність і у жінок, і у чоловіків. Проте для осіб кожної статі виявлено ділянки максимальної та мінімальної щільності кожного хребця, а також визначено можливі варіанти їхнього співвідношення, зокрема ті, які трапляються найчастіше.

Впродовж останніх років одне з чільних місць серед захворювань, які є причиною тимчасової втрати працездатності посідають патології опорно-рухового апарату, зокрема патології хребта [197]. Значний відсоток вертебрологічних патології - сколіози, остеохондроз, міжхребцеві кили тощо, виникають в результаті дії на організм різних чинників (гіподинамія, неадекватні фізичні навантаження, порушення обмінних процесів) та проявляються різного ступеня вираженості змінами в міжхребцевих дисках [198]. Очевидно, що раннє виявлення таких змін, ще до виникнення клінічних проявів хвороби, дозволить проводити їх ранню корекцію і запобігти розвитку патологічного процесу. Тому актуальним сьогодні є пошук діагностичних методів обстеження пацієнтів, які дозволили б виявити ознаки розвитку патології на доклінічних етапах та розпрацювання критеріїв ранньої діагностики, для чого необхідне глибоке і досконале вивчення структур хребетного стовпа в нормі з урахуванням вікових, статевих, конституційних та індивідуальних особливостей $[199,200]$. 


\section{ЛІТЕРАТУРА}

1. Логаш М, Покотило П. Деякі аспекти історії опіатів в контексті сучасних проблем наркозалежності. Світ Медицини Та Біології.2013;4(41):126-9.

2. Leppert W. The place of oxycodone/naloxone in chronic pain management. Contemp Oncol Pozn.2013;17(2):128-133.

3. Beaver WT, Feise GA. A comparison of the analgesic effect of intramuscular nalbuphine and morphine in patients with postoperative pain. J Pharmacol Exp Ther.1978;204(2):487-496.

4. Свиридова Н.К. Боль в нижней части спины. Междунар. неврол. журн. 2016. № 5(83). С. 130-134.

5. Баринов А.Н. Боль в спине: новые технологии и старые предрассудки. А.Н. Баринов, К.А Махинов, Д.А Сергиенко. Фарматека. 2016. № 7.

6. Helm I.S. et al. Percutaneous adhesiolysis in the management of chronic low back pain in post lumbar surgery syndrome and spinal stenosis: a systematic review. Pain Physician. 2012. 15. 435-462.

7. Gear R, Becerra L, Upadhyay J, Bishop J, Wallin D, Pendse G, et al. Pain facilitation brain regions activated by nalbuphine are revealed by pharmacological fMRI. PloS One.2013;8(1):e50169.

8. Habibey R, Pazoki-Toroudi H. Morphine dependence protects rat kidney against ischaemia-reperfusion injury.Clin Exp Pharmacol Physiol. 2008;35(10):1209-1214

9. Lord JA, Waterfield AA, Hughes J, Kosterlitz HW. Endogenous opioid peptides: multiple agonists and receptors. Nature.1977;267:495-499.

10. Manallack DT, Beart PM, Gundlach AL. Psychotomimetic $\sigma$-opiates and PCP. Trends Pharmacol Sci. 1986 Jan 1; 7:448-51.

11. Лишманов Ю., Нарыжная Н., Цибульников С., Маслов Л., Колар Ф., Жанг И., и другие. Роль $\mu-$, бИ копиоидных рецепторов в формировании кардиопротекторного эффекта адаптации к хронической нормобарической гипоксии. Сибирский Медицинский Журнал.2012;27(1):111-4.

12. Маслов Л, Лишманов А, Цибульников С. Роль протеинкиназы с, ERK- киназы, NO-синтазы и КАТфканалов в механизме антиаритмического действия опиоида U-50,488 при кратковременной ишемии и реперфузии сердца in vivo. Сибирский Медицинский Журнал.2013;28(1):97-101.

13. WeeS, Koob GF. The role of the dynorphin- $\kappa$ opioid system in the reinforcing effects of drugs of abuse. Psychopharmacology (Berl). 2010;210(2):121-135.

14. Trescot AM, Datta S, Lee M, Hansen H. Opioid pharmacology. Pain Physician. 2008;11(2 Suppl):S133-53.

15. Feng Y,He X, Yang Y,Chao D, H Lazarus L, Xia Y.Current research on opioid receptor function. Curr Drug Targets.2012;13(2):230-246.

16. Holzer P. Opioid receptors in the gastrointestinal tract. Regul Pept. 2009;155(1):11-17.

17. Ветриле С.Т. Краниовертебральная патология. С.Т. Ветриле, С.В. Колесов. М.: Медицина, 2007. - 320 с.

18. Воронович И.Р. Изменение деятельности нейромышечной, дыхательной и сердечно-сосудистой систем у детей, больных сколиозом. И.Р. Воронович, О.С. Казарин, О.И. Шалатонина. Ортопед., травматол. и протезиров. 2004. № 11. С. 61-64.

19. Этиология острой кривошеи у детей. А.В. Губин, Э.В. Ульрих, А.Н. Ялфимов, А.И. Тащилкин. Актуальные проблемы детской травматологии и ортопедии: матер. научно-практ. конф. с международным участием. Казань, 2008. С. 170- 171.

20. Проценко В.Н. Асиметрии строения теля современного человека. Клинико-диагностические аспекты. Часть 1 В.Н. Проценко, В.В. Беляков. Мануальная терапия. 2010. № 1(37). С. 75-84.

21. Шевага В.М. Остеохондроз хребта: від патогенетично обгрунтованого діагнозу характеру больового синдрому до ефективного лікування. В.М. Шевага. Міжнарод. невролог. ж. 2006. № 3(7). С. 40- 44.

22. Смирнов В.В. Лучевая диагностика травматических повреждений шейного отдела позвоночника. В.В. Смирнов, Н.П. Елисеев, Г.М. Раковская. Мануальная терапия. 2009. № 3(35). С. 81-91.

23. Association between osteoporosis and no-related metabolic disorders in rats. O.O. Adamovych, O. Zayachkivska, O. Kordiyak, A. Safonov. 5th international symposion of clinical and applied anatomy and 1st paneuropean meeting of anatomists. Graz, Austria, 24-26 May 2013. Graz, 2013. P. 97. 